огляди

\title{
Plant sulfolipid. 1. Functions
}

\author{
A. A. Okanenko, N. Yu. Taran, O. I. Kosyk
}

National Taras Shevchenko University

64 Volodymyrska str., Kyiv, Ukraine, 01033

tarantul@univ.kiev.ua

\begin{abstract}
Plant sulpholipid, sulfoquinovosyl diacylglycerol (SQDG) has been found almost in all photosynthetic organisms. SQDG appears to be concentrated mainly in the chloroplasts of plants, as in envelope so and in lamellar membranes. It is associated with purified chloroplast CF0-CF1 ATPase and supposed does not form lipid matrix but plays a more specific role in the catalytic activity of proteins. SQDG molecules were found in the association of the LHC II-apoproteins and are localised as prosthetic groups at the surface of native D1/D2 heterodimer. Results recent works showed that the physical properties of the PS II complex were altered by the loss of SQDG: for the stable activity PS II needs the presence of SQDG.
\end{abstract}

Keywords: glycolipid, sulfolipid, sulfoquinovosyldiacylglycerol, SQDG.

Introduction. In modern scientific world of plant science cell membrane lipid component physiological role remained not investigated completely although it is proved that biological membrane fluidity plays a significant role in the perception of signals generated by environmental changes. Photosynthetic membrane lipid component peculiarities are substantially different from other types of biomembranes because they are closely related to the photosynthetic apparatus functioning. The presence of pigment in photosynthetic membranes and some characteristics of lipid matrix make them unique. Therefore our laboratories was engaged in investigation of just these lipid compounds. For a long time we studied the environmental factor action upon the lipid composition of different plants, and results obtained attracted our attention to sulfolipid behaviour, as in fruit trees, so in cereals. Therefore it became a cause of our interest to this compound identified as sulfoquinovosyl diacylglycerol (SQDG). It is known as plant sulfolipid

(C) A. A. OKANENKO, N. Yu. TARAN, O. I. KOSYK, 2008 that contains a sulfonic acid linkage characterized by carbon being directly bound to sulfur as $\mathrm{CsSO}_{3}-$ in contrast to the sulfate ester of animal sulfatides. It comprises between 8 and $24 \%$ of the four major chloroplast lipids and contains a substantial quantity of high melting point fatty acids $(16: 0+18: 0)$, in the range between 26 (Triticum aestivum) and $62 \%$ (Carica papaya) [1, 2]. This substance with the structure of 1,2-di-O-acyl-3-O-(6-deoxy-6-sulfo-a-Dglucopyranosyl)-sn-glycerol was discovered by Andrew Benson with colleagues in 1959 [3]. Sulfonic acid of this type is chemically stable and strong acid in wide $\mathrm{pH}$ range [4]. Sulfoquinovose and its glycosides, glyceryl sulfoquinovoside and the SQDG comprise the most concentrated anionic sugar derivatives in plants under various conditions [5]. SQDG function is not known completely although it is not restricted to chloroplast membranes and a role in the regulation of ATPases has been proposed [6].

Occurrence. SQDG has been found almost in all photosynthetic plants, algae, cyanobacteria, purple sulfur and non-sulfur bacteria [7]. In algae SQDG 


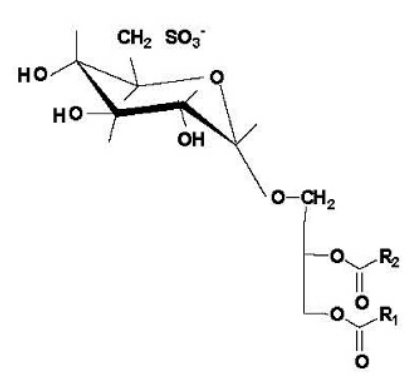

quantity is usually higher than in higher plant chloroplasts and about $70 \%$ of the alga's sulfolipid is localized in the thylakoid $[8,9]$. Sometimes in algae SQDG quantity surpasses other glycolipid content viz. Fucus vesiculosus has $22 \%$ SQDG, $15 \%$ of monogalactosyldiacylglycerol (MGDG) and $11 \%$ of digalactosyldiacylglycerol (DGDG). In other algae SQDG content was comparable with galactolipids content - $20 \%$ SQDG, $37 \%$ MGDG and $20 \%$ DGDG in Acetabalaria mediterranea and 29 \% SQDG, $29 \%$ MGDG and $18 \%$ DGDG in Chattonella antiqua [10].

Cyanobacteria that belongs to the genus Chroococcidiopsis are widespread in nature and lipid composition of three wild terrestrial strains of this genus (Order Chroococcales): C. supralittoralis, C. umbratilis and C. vesanlis contain high quantity of SQDG. C. supralittoralis has $22.1 \%$ versus $38.4 \%$ of MGDG and $19.5 \%$ of DGDG. C. umbratilis has $27 \%$ versus $28.9 \%$ of MGDG and $19.5 \%$ of DGDG, and C. vesanlis $-31.6 \%$ at $14.5 \%$ of MGDG and $20.6 \%$ of DGDG of total polar lipid quantity [11]. In photosynthetic purple bacterium Rhodobacter sphaeroides SQDG content varies depending upon the conditions from $2.2 \%$ up to $16.6 \%$ (at phosphate starvation) [12], in Rhodospirillum rubrum - 2,6\% [13]. In some lichens the SQDG content sometimes surpasses the MGDG (Trebouxia impressa twice) and the DGDG (Trebouxia erici) content [14]. In the moss Rhytidiadelphus squarrosus (Hedw.) Warnst. SQDG content was more than $18 \%$ of total glycolipids (whereas MGDG quantity was $55.8 \%$ and DGDG $25.7 \%)$ [15].

Concerning this lipid acyl composition we could notice that major molecular species contain both palmitic and linolenic fatty acid residues $[5,16,17]$. Dilinolenoyl and dipalmitoyl SQDG usually occurred in less amount $[16,17]$. But in some algae palmitic acid residue was the main acyl group. So Antarctic sea ice diatoms (the algal composition in the culture was $66 \pm$ $\pm 11 \%$ of Navicula gelida var. antarctica, $20 \pm 7 \%$ of Fragilariopsis curta and $14 \pm 9 \%$ of Nitzschia medioconstricta had SQDG with $28.58 \%$ of palmitic acid residue [18]. SQDG of red algae Anfeltia tobuchiensis contained $31.5 \%$, brown algae Laminaria japonica $-45.2 \%$ and green algae Ulva fenestrata $58.7 \%$ of the total fatty acid content [19]. There are some plants that have significant amounts of oleic (Nerium oleander L., 12-14 \%) and linoleic (Caricaceae, Passifloraceae, 10-16\%) residue [1, 17], sometimes surpassing linolenic residue content - in plant Boea hygroscopica [20] and sugar beet (especially roots $-55 \%$ ) [21]. Besides, a number of unusual sulfur-containing lipids were revealed in bacteria and algae [10, 22-24], but none of the other sulfur-containing lipids can compete with SQDG in its quantity in the biosphere [25].

Localization. SQDG appears to be concentrated in the outer and in the inner chloroplast thylakoid membrane of plants. This substance occurs in both membrane regions connected with its interaction with photosystem II (PS II) (normally in the appressed region) and CF0-CF1 (localized exclusively in the non-appressed region) [5]. Sundby and Larsson [26] argued that acidic lipids located in the inner leaflet of the bilayer could act as counterions for protons accumulated in the lumen and even serve as proton conducting pathways supporting Haines [27] proposal. Much less quantities of this compound was found in plant mitochondria - in mitochondrial lipids from avocado fruit 0.9 and $1.3 \%$ of total lipid in cauliflower buds and 3.6 and $2.5 \%$ in chloroplasts respectively. These quantities expressed per mg protein $\mathrm{N}$ were 99 and $56 \mathrm{nmol}$ respectively and 135 and $95 \mathrm{nmol}$ respectively [28]. In plant roots $0.084-0.188 \mathrm{mmol}$ of the lipid per $1 \mathrm{~g}$ of fresh wheat roots and 0.087 $0.113 \mathrm{mmol}$ per $1 \mathrm{~g}$ of fresh oat roots depending on growing condition was found [29]. According to our data SQDG content in 8-day old wheat seedling roots was $0.12-0.35 \mathrm{mmol}$ lipid per $1 \mathrm{~g}$ of fresh matter. But SQDG content amounted to $12-18 \%$ in bean roots [30] and 19.5, 28 and $37.0 \%$ of total extractable lipids in leaves, stalks, and roots sugar beet grown in climate chamber [21]. 
Functions. Considering evidence available about SQDG functions in plant we should arrange it in some levels: a) structural; b) SQDG-pigment interaction; c) SQDG-protein interaction (including thylakoid proteins and enzyme activity regulation); d) SQDGprotein transport.

A structural role of SQDG. A structural role for SQDG has been proposed in that the lipid might occupy regions in the leaflet opposite to MGDG inverted micelles or the region on the convex side of the bulge or cusp in corresponding models of lipid particles. Experiments showed that addition of SQDG to mixtures of MGDG and DGDG induced the appearance of paracrystalline arrays of 8-10 nm lipid particles with number increased at increased SQDG concentration. It was proposed that the orderly arranged lipid particles containing negatively charged SQDG might be the basis for the orderly arrangement of other thylakoid molecules functioning in photosynthesis [31]. In addition to effects on proteins themselves, charged lipids can also regulate membrane properties in general. They suppress the formation of non-bilayer structures by imposing a bilayer arrangement on MGDG-enriched preparations [32]. The balance between the charged SQDG or phosphatidylglycerol (PG) and the uncharged galactolipids is probably controlled by the regulation of MGDG synthesis: the activity of UDP-galactose: diacylglycerol galactosyl transferase being altered by negatively-charged lipids - PG most, phosphatidylinositol (PI) and SQDG [33, 34].

Haines [27] proposed that the lipid anionic headgroups of the energy transducing membranes could bind and conduct protons along the membrane surface. Anionic groups (such as the head-group of SQDG) were considered to form acid-anion dimers with two anions sharing a single proton via a hydrogen bond. Such putative acid-anion dimers may be protonated and deprotonated at a high rate, allowing protons to be conducted over long distances without exchanging with the bulk phase.

SQDG-chlorophyll interaction. A. Benson [35] was the first supposed that SQDG might assist the orientation of chlorophyll molecules in the membranes. Anderson [36] considered that chlorophyll-protein complexes has to be surrounded by boundary layers made up partly from the phytyl chains of chlorophyll molecules associated with the complexes and partly from boundary anionic lipid (particularly SQDG) components of the membranes. In addition, the correlation between the appearance of chlorophyll and SQDG concentration in photosynthetic tissues was found and amount of SQDG increased on greening of etiolated tissue or on maturation of chloroplasts [37]. In our earlier experiments we found the correlation between the SQDG content and bound form of chlorophyll in wheat plants treated with physiological active compounds and drought factors [38]. Moreover, it was suggested, that SQDG has to be connected with xanthophyll metabolism. Thus, the violaxanthin de-epoxidase independent conversion of violaxanthin into aurixanthin and some isomers which occurred in the presence of SQDG and PG could be explained by the acidic character of these lipids [39, 40].

SQDG-protein interaction. SQDG has been found to be closely associated with certain membrane proteins. This association is probably partly stabilized by electrostatic interactions between its negatively charged sulfonate group and positive charges within the proteins. Among chloroplast glycerolipids known to be accessible on the cytosolic face of the outer envelope membrane, SQDG and probably PI, would be the sole candidates for a putative $\mathrm{Ca}^{2+}$-dependent interaction with annexins at the chloroplast surface. $\mathrm{Ca}^{2+}$ plays a major role in stimulus-response coupling for many plant cell signaling pathways [41]. A variety of stimuli, including light, touch, and orientation changes, can induce a sharp increase in the equilibrium level of free $\mathrm{Ca}^{2+}$ in the cytoplasm of plant cells. In the case of pollen tubes it has been shown the higher level of $\mathrm{Ca}^{2+}$ at the tip [42] and it has been suggested that annexins may be one of the target for this $\mathrm{Ca}^{2+}$ signal. Annexins are characterized by their ability to bind to specific phospholipids in a $\mathrm{Ca}^{2+}$-dependent manner. They are often considered to regulate membrane organization, traffic, ion conductance across membranes and enzyme activity. A 34-kD annexin of cotton fibers that inhibits the activity of callose synthase, a plasma membrane-localized enzyme is described, but maize annexins are associated with ATPase activity [43]. These findings suggest that one of the ways that some plant annexins might exhibit their cellular effects is by regulating enzyme activity. This point is interesting 
because ATPases activity is supposed to connect with SQDG binding (see SQDG-ATPases).

Native annexin is able to interact, in vitro, with glycerolipids (SQDG and probably PI) present in the outer leaflet of the outer chloroplast envelope membrane. In the presence of $2 \mathrm{mM} \mathrm{Ca}^{2+}$ all s were fixed to the vesicles containing PI, PG or SQDG and only a partial interaction was observed with MGDG and DGDG. In the presence of $500 \mu \mathrm{M} \mathrm{Ca}^{2+}$, more than $50 \%$ of annexin was found in fractions obtained from $\mathrm{PC} / \mathrm{PI}$ and PC/SQDG vesicles. PC/PG vesicles also promote annexin interaction at this calcium concentration, but the percentage of bound protein is lower than for PI and SQDG. No interaction was detected with MGDG and DGDG. In the presence of $100 \mu \mathrm{M} \mathrm{Ca}^{2+}$, annexin was still able to bind to PC/PI, $\mathrm{PC} / \mathrm{SQDG}$ and $\mathrm{PC} / \mathrm{PG}$ vesicles, but at $500 \mu \mathrm{M} \mathrm{Ca}{ }^{2+}$ concentration, less protein was found associated to $\mathrm{PC} / \mathrm{PG}$ vesicles. These results demonstrate that native cytosolic annexin in vitro displays the high affinity for SQDG and PI [44].

Information about SQDG and the Rieske protein interaction in the cyt $b 6 f$ structures is also available [45]. In the Chlamydomonas structure, an endogenous SQDG interacts via hydrogen bonds with Rieske protein Arg13 and Asn17 and cyt $f$ Lys272. Residues Arg13 and Asn17 are conserved in cyt b6f Rieske proteins. Lys 272 has been established as a key residue in the control of cyt $f$ synthesis [46]. This suggests that the region delimited by the endogenous sulfolipid, the Rieske protein, and the cyt $f$ helix plays a specific role in the assembly-mediated control of cyt $f$ synthesis. Authors consider SQDG seems to be involved in the turnover of cyt $f$ in a similar manner like D1 and raise the question of whether a similar mechanism underlies the role of SQDG in the assembly of both subunits [45].

The study of the influence of different thylakoid lipids on the efficiency of cyt $c$ reduction in liposomes by plastoquinol-9 (plastoquinol-plastocyanin reductase) showed that, in the absence of negatively charged lipids ( $P G$ and SQDG), the reaction is inhibited severely and it terminates after 2-3 min, probably due to aggregation of liposomes. These observations suggest that the presence of charged thylakoid lipids (PG and SQDG) is indispensable for cyt $c$ adsorption to membranes [47].
SQDG and PS II. SQDG was found in the reaction centre (RC) of PS II. Only certain molecular species of SQDG were found here, viz. palmitic, stearic and oleic residues made up most of the lipid present [48]. The bound SQDG and DGDG were localized at the surface of the native D1/D2 heterodimer $(66 \mathrm{kDa})$ and bound SQDG might, therefore, hold the dimer together [49, 50]. Tight binding of certain lipids to defined peptides of the PS II core has a functional significance, since treatment with antibodies inhibits electron transport on the donor side of PS II [51]. However, Murata et al. [52] showed that the MGDG was the only lipid found in the PS II RC. The PS II core complex contained MGDG, DGDG and PG, but it lacked SQDG. These authors concluded that SQDG did not contribute to the activity of PS II.

Results of study of Nicotiana tabacum indicate that D1-peptide isolated via SDS-polyacrylamide gel electrophoresis contained MGDG, PG and SQDG molecules bound in the molar ratio 1:3:17. It was shown by Western blotting that the $66 \mathrm{kDa}$ band of the isolated dimeric D1 reacts positively only with the antisera to MGDG, SQDG, $\beta$-carotene and violaxanthin. The lipid analysis of $N$. tabacum LHC II showed that it contained in bound form 3 molecules of MGDG, 1 molecule of DGDG, 1 molecule of PG and 1 molecule of lutein. Less than 1 molecule of sulfolipid, $\beta$-carotene, neoxanthin and violaxanthin were found. Only the antiserum to MGDG and PG and among the carotenoid antisera to $\beta$-carotene, violaxanthin and to neoxanthin reacted in the Western blot analysis. With the antisera to the DGDG, to the SQDG and the antisera to the xanthophylls, namely to lutein and neoxanthin, a positive reaction occurred only in the «total» PS II-preparation [53].

SQDG and LHC II. Krupa et al. [54] noted that SQDG was the major lipid in LHC II after treatment with galacto- and phospholipases. Since from 20 to $25 \%$ of the complex was still present as an oligomer, it was argued that SQDG was involved in stabilizing LHC II. Results presented by Sigrist at al. [55] showed that LHC II-complexes of $C$. reinhardtii were enriched in SQDG with palmitate. It was calculated that $40 \%$ of the thylakoid SQDG was tightly associated with LHC II, thus every LHC II-apoprotein was associated with two molecules of SQDG bound exclusively by 
hydrophobic interactions. The high degree of saturation of bound SQDG (75\% palmitate; $50 \%$ dipalmitoyl SQDG species) facilitated the interaction between this compound and protein. It was also shown by Remy et al. [56] that the oligomeric form of the LHC II-complex is enriched in both SQDG and PG [57]. Monomerization of the complex resulted in loss of PG but not SQDG. The lipid may play a role in establishing the correct tertiary structure thus allowing proper interaction between LHC II components. In addition, intermolecular hydrophobic interactions were reported between the anionic SQDG and a $25 \mathrm{kDa}$ polypeptide [51] which was characterized by high levels of phosphorylation [58]. This information allows us to suggest that SQDG might be involved in regulation of light energy distribution between the two photosystems via the phosphorylation of the mobile antennae.

Besides, there is a suggestion concerning a role of SQDG in PS II core complex dimerization. The low molecular mass protein PsbH of the PS II core dimer contains a cluster of positively charged residues located at the stromal surface of its single transmembrane helix [59]. This region could be a site for binding PG and is also the region of reversible N-terminal phosphorylation [60]. Therefore it looks like conceivable that SQDG could substitute $\mathrm{PG}$ in the dimerization processes in the case of phosphate starvation. But experiments with $C$. reinhardtii grown under sulfur or phosphorus limitation showed that decreases in PG levels were not as obvious as the reduction in SQDG content under sulfur-limited conditions. These data may reflect the fact that PG plays some essential role that cannot be substituted by SQDG [61, 62]. On the other hand, it is known that phosphorus deficiency can induce SQDG accumulation. Thus, it seems conceivable that SQDG is able to substitute PG at least partly in the case of phosphorus deficiency.

SQDG and ATPases. In some cases the interactions may be very strong suggesting the ability of saturated SQDG molecules to associate with purified chloroplast CF0-CF1 ATPase [63]. Since SQDG removal caused the protein complex inactivation it was assumed the lipid was an integral part of the complex. Barber and Gounaris [5] have suggested that SQDG neither contributes significantly to the bulk lipid matrix nor is involved in «protein packing» like MGDG, but plays a more specific and intimate role in catalytic protein activities. Molecular species of SQDG involved in enzymatic activity are thought to contain a high amount of saturated acyl fatty acid chains and, perhaps, therefore act as «boundary» lipid. It was shown also that SQDG protects CF1 against cold inactivation in the presence of ATP. CF1 bound to membranes was found to be much more resistant to heat and cold than solubilized protein. Binding of CF1 to membranes is promoted by lipids and SQDG was considerably more effective than the galactolipids and phospholipids. Mitochondrial CF1 is similarly protected by phospholipids and SQDG both, but they were equally effective [64].

It looks like SQDG in roots and non-photosynthesizing tissues is involved in ATPase function. It has been reported that activity of the bean root ATPase, extracted with acetone, could be partially restored by addition of lipids. In this case SQDG was the most efficient, whereas small or insignificant effects were obtained with phosphatidylethanolamine, PG and MGDG. DGDG and PI were completely ineffective [30].

P. J. C. Kuiper suggested that a lipid composition change induced by a shift of temperature could affect the ATPase temperature response in vivo. In addition, SQDG was proposed to be essential for an active microsomal $\mathrm{Na}^{+} / \mathrm{K}^{+}$-stimulated ATPases. A net negative surface charge may be a prerequisite for attracting the highly mobile univalent cations $\mathrm{Na}^{+}$and $\mathrm{K}^{+}$and, thus, for maintaining the function of the lipoprotein complex [21]. Recent experiments showed that increased activity of F-ATPase localized in chloroplast and mitochondria correlated with $\mathrm{NaCl}$ concentrations in the growth medium in Aster and, to a less extent, in Sesuvium. This phenomenon was accompanied by significant increase of SQDG content in these species. Authors concerned that this increase has to be involved in stabilization of ATPase complexes and PS II-Aster F-ATPase activity increased with increasing $\mathrm{NaCl}$ concentration in the growth medium $[65,66]$. These results confirmed the suggestion that sulfolipids stabilize and/or activate F-ATPases. Thus, taking into account that plenty of metabolic processes and adaptative reactions flow 
engaging ATPases, one could suppose the extent of SQDG involvement in these processes.

SQDG and other enzyme activity. Some experiments demonstrate a regulatory role of SQDG in enzyme activity. This association probably occurs by electrostatic interactions between the negative part of the glycolipid (sulfonate), and positive charges of the proteins. Particularly, the interaction of lipid-activated phospholipase $\mathrm{A}_{2}\left(\mathrm{PLA}_{2}\right)$, an enzyme responding in a dose-dependent manner, with more saturated SQDGs caused less activation. The activation took place at very low SQDG concentrations and high concentrations failed to increase activation further. Using intrinsic fluorescence to detect conformational changes in proteins due to substrate or ligand binding, it was found that the fluorescence intensity of porcine pancreatic $\mathrm{PLA}_{2}$ was drastically enhanced in presence of SQDG. It was interpreted as indication of transition from the inactive to the hypothetical active state of the enzyme-bilayer complex [67].

The activity of another lipid-metabolizing enzyme, the UDP-galactose:diacylglycerol galactosyltransferase, is enhanced with negatively charged lipids ( $P G$ most, PI and SQDG) [34]. On the other hand, chlorophyllase activity assays show that anionic lipids (PG and SQDG) can associate with isolated enzyme preparations, thereby inactivating them in a co-operative fashion. The extent of this inactivation depends on the $\mathrm{pH}$ and ionic strength of the reaction medium and can be reversed by divalent cations [68]. Besides, Baccio et al. [69] considered that anionic lipids SQDG and PG are able to interact with the basic protochlorophyllide oxidoreductase complexes, stabilizing the prolamellar body structure. In addition, inhibitory activity of aggregated SQDG was observed toward $\beta$-glucosidase. Deacylated SQDG derivatives showed no inhibition and, therefore, it was assumed that inhibition by SQDG required the hydrophobic acyl groups perhaps to produce an aggregate and/or to interact with a hydrophobic site in the enzyme. The competition between SQDG and DGDG in mixed micelles were suggested to reduce access of SQDG to the $\beta$-glucosidase and to suppress the inhibition [70, 71].

Another property attributed to SQDG is a potenlial effect against AIDS virus [72]. Extracts of SQDG and sulfoquinovosyl monoacylglycerol (SQMG) from lower plants was shown to be potent inhibitors of DNA polymerases $\alpha$ and $\beta$ in vitro and effective antineoplastic agents. SQDG and SQMG with longer acyl chains were more effective than those with shorter chains, especially SQMG containing $18 \mathrm{C}$ acids. Both isomers were effective against DNA polymerase $\alpha$ and $\beta$. DNA polymerase $\alpha$ was non-competitively inhibited. Both SQMG and SQDG were also effective as antagonists of both template-primer DNA-binding and nucleotide substrate-binding of DNA polymerase [73]. Data from other studies showed that SQDG isolated from a marine red alga, Gigartina tenella, inhibited eukaryotic DNA polymerases and HIV-reverse transcriptase type 1 in a dose-dependent manner [74]. It was found that the mode of inhibition of DNA polymerase and human immunodeficiency virus reverse transcriptase (HIV RT) was competitive with the DNA template primer and was non-competitive with the substrate deoxythymidine triphosphate. In both cases the whole molecular structure is required for inhibition which was abrogated by loss of the sulfonate from position 6 of the hexose ring $[75,76]$.

Role SQDG in protein transport. It is known that transit peptides are necessary for targeting and translocation of chloroplast proteins into the chloroplast interior [77]. These peptides are rich in basic amino acids. This property may facilitate their interactions with acidic lipids and effective insertion into monolayers of PG, SQDG and MGDG [50]. The anionic lipids seem to be the strongest determinants for protein insertion. For example, the transit peptides of the small subunit of Rubisco (SSU) [78] and ferredoxin (Fd) $[79,80]$ interact with MGDG, SQDG and PG, whereas the transit peptide of outer chloroplast envelope membrane protein toc 75 is inserted only into the negatively charged chloroplast lipids, SQDG and PG. However, experiments performed in order to establish whether electrostatic or hydrophobic interactions were the more important in determining interactions with lipids showed that insertion of proteins into monolayers of total lipid extracts from the chloroplast outer membrane was not reduced by high salt (masking the negative charge of the anionic lipids). Thus hydrophobic interactions seems to be dominant in determining interactions. A similar conclusion was 
made for the interaction of peptides corresponding to different regions of the transit sequence of the small subunit of ribulose bis-phosphate carboxylase with outer membrane lipids [78].

During interaction with membrane lipids in small unilamellar vesicles, peptide transit sequences can undergo a two-state random coil-helix transition [81]. Anionic lipids like PG or SQDG are strong $\alpha$-helix promoters. They can convert up to $50 \%$ of the polypeptide into a helical conformation. The location of the induced $\alpha$-helices within the overall peptide is not known. The only precise information available concerns the transit peptide of ferredoxin from C. reinhardtii, and Lancelin et al. [82] argue that the $\alpha$-helix is localized at the N-terminus. The model proposed assumes the newly synthesized precursor to interact initially via its transit sequence with cytosol-exposed lipid domains in outer membrane. The C-terminus of the transit sequence is suggested to interact with anionic lipids whereas the N-terminus interacts preferentially with chloroplast specific MGDG. These interactions are followed by insertion of both domains into the lipid layer. Besides, it has been demonstrated in vitro that import of cytoplasmically synthesized proteins into chloroplasts requires ATPase activity [83], which in turn are SQDG-bind enzymes.

Thus, one could see that SQDG is multifunctional compound presumably supporting energy transforming processes. In the next part we consider results of experiments with SQDG-deficient mutants supporting some of the information presented.

О. О. Оканенко, Н. Ю. Таран, О. І. Косик

Сульфоліпід рослин. 1. Функції

Резюме

Рослинний сульфоліпід сульфохіновозилдіацилглічерол (СХДГ) знайдено практично в усіх фотосинтезувальних організмах. СХДГ концентрується переважно у хлоропластах рослин як в оболониі, так і в мембранах ламел. СХДГ зв'язується з очищеною СF0-CF1 АТФазою хлоропластів $i$, як вважають, не формує ліпідної матрииі, але при иьому його вплив на каталітичну активність білків є спеиифічнішим. Молекули СХДГ асоиійовані з LHC II-апопротеїнами і локалізовані як простетичні групи на поверхні нативного гетеродимеру D1/D2. Результатами останніх робіт показано, шоо фізичні властивості комплексу ФС ІІ змінюються із втратою СХДГ: для стабільного функиіонування ФС II необхідна його присутність.

Ключові слова: гліколіпід, сульфоліпід, сульфохіновозилдіацилглічерол, СХДГ.

\section{А. А. Оканенко, Н. Ю. Таран, О. И. Косик}

Сульфолипид растений. 1. Функции

Резюме

Растительный сульфолипид сульфохиновозилдиацилглицерол (СХДГ) обнаружен практически во всех фотосинтезирующих организмах. СХДГ конщентрируется преимущественно в хлоропластах растений как в оболочке, так и в мембранах ламелл. СХДГ связывается с очищенной CF0-CF1 АТФазой хлоропластов и, как считают, не формирует липидной матрииы, но при этом его влияние на каталитическую активность белков более специфично. Молекуль СХДГ ассоциированы с LHC II-апопротеинами и локализованы как простетические группы на поверхности нативного D1/D2 гетеродимера D1/D2. Результатами последних работ показано, что физические свойства комплекса ФС ІІ изменяются с потерей СХДГ: для стабильного функиионирования ФС II необходимо его присутствие.

Ключевые слова: гликолипид, сульфолипид, сульфохиновозилдиацилглицерол, СХДГ.

\section{REFERENCES}

1. KenrickJ., Bishop D. The fatty acid composition of phosphatidylglycerol and sulfoquinovosyl diacylglycerol of higher plants in relation to chilling sensitivity // Plant Physiol.1986.-81, N 4.-P. 946-948.

2. Murata N., Siegenthaler P. A. Lipids in photosynthesis: an overview // Lipids in photosynthesis: structure, function and genetics / Eds P. A. Siegenthaler, N. Murata.-Dordrecht: Kluwer Acad. Publ., 1998.-P. 3-20.

3. Benson A. A. A sulfolipid in plants // Proc. Nat. Acad. Sci. USA.-1959.-45, N 11.-P. 1582-1587.

4. Barber J., Gounaris K. What role does sulfolipid play within the thylakoid membrane? // Photosynth. Res.-1986.-9, N 12.- P. 239-249.

5. Benson A. A. The plant sulfolipid // Advances in lipid research 1.-New York: Acad. press, 1963.-P. 387-394.

6. Harwood J. L. Sulfolipids // The Biochemistry of plants / Eds P. K. Stumpf, E. E. Conn.-New York: Acad. press, 1980.P. 301-320.

7. Wada H., Murata N. Membrane lipids in Cyanobacteria // Lipids in photosynthesis: structure, function and genetics / Eds P. A. Siegenthaler, N. Murata.-Dordrecht: Kluwer Acad. Publ., 1998.-P. 83-101.

8. Janero D. R., Barrnett R. Cellular and thylakoid-membrane glycolipids of Chlamydomonas reinhardtii 137+ // J. Lip. Res.-1981-22, N 7.-P. 1119-1125.

9. Harwood J. L. Membrane lipids in algae // Lipids in photosynthesis: structure, function and genetics / Eds P. A. Siegenthaler, N. Murata.-Dordrecht: Kluwer Acad. Publ., 1998.-P. 53-64.

10. Harwood J. L., Jones A. L. Lipid metabolism in algae // Adv. Bot. Res.-1989.-16.-P. 1-53.

11. Rezanka T., Viden I., Go J. V., Dembitsky V. M. Polar lipids and fatty acids of three wild cyanobacterial strains of the genus Chroococcidiopsis // Folia Microbiol.-2003-48, N 6.P. 781-786.

12. Benning C., Beatty J. T., Prince R. C., Somerville C. R. The sulfolipid sulfoquinovosyldiacylglycerol is not required for photosynthetic electron transport in Rhodobacter 
sphaeroides but enhances growth under phosphate limitation // Proc. Nat. Acad. Sci. USA.-1993.-90, N 4.-P. 1561-1565.

13. Russell N. J., Harwood J. L. Changes in the acyl lipid composition of photosynthetic bacteria grown under photosynthetic and non-photosynthetic conditions // Biochem. J.-1979-181, N 2.-P. 339-345.

14. Бычек-Гущина И. А. Изучение биохимических аспектов лишайникового симбиоза. І. Липиды и жирные кислоты культивируемых симбионтов лишайников // Биохимия.1997.-62, № 5.-C. 571-580.

15. Guschina I. A., Harwood J. L. Lipid metabolism in the moss Rhytidiadelphus squarrosus (Hedw) Warnst. from lead-contaminated and non-contaminated populations // J. Exp. Bot.-2002-53, N 368.-P. 455-463.

16. Murata N., Hoshi H. Sulfoquinovosyl diacylglycerols in chilling sensitive and chilling resistant plants // Plant Cell Physiol.-1984.-25, N 7.-P. 1241-1245.

17. Orr G., Raison J. Compositional and thermal properties of thylakoid polar lipids of Nerium oleander L. in relation to chilling sensitivity // Plant Physiol.-1987.-84, N 1.-P. 8892 .

18. Mock T., Kroon B. M. A. Photosynthetic energy conversion under extreme conditions - II: The significance of lipids under light limited growth in Antarctic sea ice diatoms // Phytochemistry.-2002.-61, N 1.-P. 53-60.

19. Sanina N. M., Goncharova S. N., Kostetsky E. Y. Fatty acid composition of individual polar lipid classes from marine macrophytes // Phytochemistry.-2004.-65, N 6.-P. 721-730.

20. Navari-Izzo F., Ricci F., Vazzana C., Quartacci M. F. Unusual composition of thylakoid membranes of the resurrection plant Boea hygroscopica: Changes in lipids upon dehydration and rehydration // Physiol. Plant.-1995.-94, N 1.- P. 135-142.

21. Kylin A., Kuiper P. J. C., Hansson G. Lipids from sugar beet in relation to the preparation and properties of (sodium + potassium)-activated adenosine triphosphotases // Physiol. Plant.-1972.-26, N 2.-P. 271-278.

22. Lopez F., Lobasso S., Colella M., Agostiano A., Corcelli A. Light dependent and biochemical properties of two different bands of bacteriorhodopsin isolated on phenyl-sepharose CL-4B // Photochem. and Photobiol.-1999.-69, N 5.-P. 599604.

23. Corcelli A., Colella M., Mascolo G., Fanizzi F. P., Kates M. A novel glycolipid and phospholipid in the purple membrane // Biochemistry.-2000.-39, N 12.-P. 3318-3326.

24. Riekhof W. R., Ruckle M. E., Lydic T. A., Sears B. B., Benning $C$. The Sulfolipids 2'-O-acyl-sulfoquinovosyl diacylglycerol and sulfoquinovosyl diacylglycerol are absent from a Chlamydomonas reinhardtii mutant deleted in SQD1// Plant Physiol.-2003.-133, N 2.-P. 864-874.

25. Heinz E. Recent investigation on the biosynthesis of the plant sulfolipid // Sulfur nutrition and assimilation in higher plants / Eds L. J. De Kok et al.-The Hague: SPB Acad. publ., 1993.P. 163-178.

26. Sundby C., Larsson $C$. Transbilayer organization of the thylakoid galactolipids // Biochim. et Biophys. Acta.-1985.813, N 1.-P. 61-67.

27. Haines T. H. Anionic lipid headgroups as a protonconducting pathway along the surface of membranes: A hypothesis // Proc. Nat. Acad. Sci. USA.-1983.-80, N 1.P. 160-164.

28. Schwertner H. A., Biale J. B. Lipid composition of plant mitochondria and of chloroplasts // J. Lip. Res.-1973.-14, N 2.- P. 235-242.
29. Kuiper P. J. C., Kahr M., Stuiver C. E. E., Kylin A. Lipid composition of whole roots and $\mathrm{Ca}^{2+}, \mathrm{Mg}^{2+}$-activated adenosine triphosphatases from wheat and oat as related to mineral nutrition // Physiol. Plant.-1974.-32, N 1.-P. 33-36.

30. Kuiper P. J. C. Temperature response of adenosine triphosphatase of bean roots as related to growth temperatures and to lipid requirement of the adenosine triphosphatase // Physiol. Plant.-1972.-26, N 2.-P. 200-205.

31. Sakai W. S., Yamamoto H. Y., Miyazaki T., Ross J. W. A model for chloroplast thylakoid membranes involving orderly arrangements of negatively charged lipidic particles containing sulfoquinovosyl diacylglycerol // FEBS Lett.1983.-158, N 2.-P. 203-207.

32. Quinn P. J. The role of lipids in stability of plant membranes // Advances in plant lipid research / Eds J. Sanches, E. Gerda-Olmedo, E. Martinez-Force--Seville: Univ. press, 1998.-P. 361- 366.

33. Coves J., Joyard J., Douce R. Lipid requirement and kinetic studies of solubilized UDP-galactose:diacylglycerol galactosyltransferase activity from spinach chloroplast envelope membranes // Proc. Nat. Acad. Sci. USA.-1985.85, N 19.-P. 4966-4970.

34. Li L., Karlsson O. P., Wieslander A. Activating amphiphiles cause a conformational changes of the 1,2-diacylglycerol transferase from Acholeplasma laidlavii membranes according to proteolitic digestion // J. Biol. Chem.-1997.272, N 47.-P. 29602-29606.

35. Benson A. A. Plant membrane lipids // Annu. Rev. Plant Physiol.-1964.-15, N 2.-P. 1-16.

36. Anderson J. M. The molecular organization of chloroplast thylakoids // Biochim. et Biophys. Acta. 1975.-416, N 2.P. 191-235.

37. Leech R. M., Rumsby M. G., Thomson W. W. Plastid differentiation, acyl lipid, and fatty acid changes in developing green maize leaves // Plant Physiol.-1973.-52, N 3.-P. 240-245.

38. Оканенко А. А., Таран Н. Ю. Действие повышенных температур и дефицита влаги на состав липидного комплекса хлоропластов листьев озимой пшеницы // Факторы среды и организация первичных процессов фотосинтеза.-К.: Наук. думка, 1989.-С. 120-126.

39. Latowski D., Kostecka A., Strzalka K. Effect of monogalactosyldiacylglycerol and other thylakoid lipids on violaxanthin de-epoxidation in liposomes // Biochem. Soc. Trans.-2000.28, N 6.-P. 810-812.

40. Latowski D., Akerlund H.-E., Strzaika K. Violaxanthin de-epoxidase, the xanthophyll cycle enzyme, requires lipid inverted hexagonal structures for its activity // Biochemistry.-2004.-43, N 15.-P. 417-420.

41. Bush D. S. Calcium regulation in plant cells and its role in signaling // Annu. Rev. Plant Physiol. Mol. Biol.-1995.-46.P. 95-122.

42. Miller D. D., Callaham D. A., Gross D. J., Hepler P. K. Free $\mathrm{Ca}^{2+}$ gradient in growing pollen tubes of Lilium // J. Cell Sci.1992.-101, N 1.-P. 7-12.

43. Clark G. B., Roux S. J. Annexins of plant cells // Plant Physiol.-1995.-109, N 4.-P. 1133-1139.

44. Seigneurin-Berny D., Rolland N., Dorne A. J., Joyard J. Sulfolipid is a potential candidate for annexin binding to the outer surface of chloroplast // Biochem. and Biophys. Res. Communs.-2000.-272, N 2.-P. 519-524.

45. De Vitry C., Ouyang Y., Finazzi G., Wollman F.-A., Kallas T. The chloroplast rieske iron-sulfur protein at the crossroad of 
electron transport and signal transduction // J. Biol. Chem.2004.-279, N 43.-P. 44621-44627.

46. Choquet Y., Zito F., Wostrikoff K., Wollman F.-A. Cytochrome $f$ translation in Chlamydomonas chloroplast is autoregulated by its carboxyl-terminal domain // Plant Cell.-2003.-15, N 6.-P. 1443-1454.

47. KrukJ., Jemioia-Rzeminska M., Strzaika K. Cytochrome $c$ is reduced mainly by plastoquinol and not by superoxide in thylakoid membranes at low and medium light intensities: its specific interaction with thylakoid membrane lipids // Biochem. J.-2003.-375, N 6.-P. 215-220.

48. Gounaris K., Barber J. Isolation and characterization of a photosystem II reaction centre lipoprotein complex // FEBS Lett.-1985.-188, N 1.-P. 68-72.

49. Vijayan P., Routaboul J.-M., Browse J. A genetic approach to investigating membrane lipid structure and photosynthetic function // Lipids in photosynthesis: structure, function and genetics / Eds P. A. Siegenthaler, N. Murata.-Dordrecht: Kluwer Acad. Publ., 1998.-P. 263-285.

50. De Kruijff B., Pilon R., Hof R., van't, Demel R. Lipid-protein interactions in chloroplast protein import // Lipids in photosynthesis: structure, function and genetics / Eds P. A. Siegenthaler, N. Murata.-Dordrecht: Kluwer Acad. Publ., 1998.-P. 191-208.

51. Radunz A., Bader K., Schmid G. Influence of antisera to sulfoquinovosyl diglyceride and to $\beta$-sitosterol on the photosynthetic electron transport in chloroplasts from higher plants // Structure, function and metabolism of plant lipids / Eds P.-A. Sieghenthaler, W. Eichenberger.-Amsterdam: Elsevier Sci. Publ., 1984.-P. 479-484.

52. Murata N., Higash S.-I., Fugimura Y. Glycerolipids in various preparation of photosystem II from spinach chloroplasts // Biochim. et Biophys. Acta.-1990.-1019, N 3.-P. 261-268.

53. Gasser A., Raddatz S., Radunz A., Schmid G. H. Comparative immunological and chemical analysis of lipids and carotenoids of the D1-Peptide and of the light- harvestingcomplex of photosystem II of Nicotiana tabacum // Z. Naturforsch.-1999.-54c, N 3-4.-P. 199-208.

54. Krupa Z., Huner N. P. A., Williams J. P., Maissan E., James $D$. R. Development at cold-hardening temperatures // Plant Physiol.-1987.-84, N 1.-P. 19-24.

55. Sigrist M., Zwellenberg C., Giroud C. H., Eichenberger W., Boschetti $A$. Sulfolipid associated with light-harvesting complex associated with photosystem II apoproteins of Chlamydomonas reinhardii // Plant Sci.-1988.-58, N 1.P. 15-23.

56. Remy R., Tremolieres A., Duval J. C., Ambard-Bretteville F., Dubacq J. P. Study of the supramolecular organization of light-harvesting chlorophyll protein (LHCP) // FEBS Lett.1982.-137, N 2.-P. 271-275.

57. Rawyler A., Siegenthaler P. A. Role of lipids in functions of photosynthetic membranes revealed by treatment with lipolytic acyl hydrolase // Eur. J. Biochem.-1980.-110, N 1.P. 179-187.

58. Larsson U. K., Andersson B. Different degrees of phosphorylation and lateral mobility of two polypeptides belonging to the light-harvesting complex of photosystem II // Biochim. et Biophys. Acta.-1985.-809, N 3.-P. 396-402.

59. Kruse O., Hankamer B., Konczak C., Gerle C., Morris E., Radunz A., Schmid G. H., Barber J. Phosphatidylglycerol is involved in the dimerization of photosystem II // J. Biol. Chem.-2000.-275, N 9.-P. 6509-6514.
60. Michel H., Hunt D. F., Shabanowitz J., Bennett J. Tandem mass spectrometry reveals that three photosystem II proteins of spinach chloroplasts contain N-acetyl-O-phosphothreonine at their $\mathrm{NH}_{2}$ termini // J. Biol. Chem.-1988.-263, N 3.P. 1123-1130.

61. Hagio M., Gombos Z., Varkonyi Z., Masamoto K., Sato N., Tsuzuki M., Wada $H$. Direct evidence for requirement of phosphatidylglycerol in photosystem II of photosynthesis // Plant Physiol.-2000.-124, N 2.-P. 795-804

62. Sato N., Hagio M., Wada H., Tsuzuki M. Environmental effects on acidic lipids of thylakoid membranes // Biochem. Soc. Trans.-2000.-28, N 6.-P. 912-914.

63. Pick U., Gounaris K., Weiss M., Barber J. Tightly bound sulfolipids in chloroplast CF0-CF1 // Biochim. et Biophys. Acta.-1985.-808, N 3.-P. 415-420.

64. Livn A., Racker E. Partial resolution of the enzymes catalyzing photophosphorylation. V. Interaction of coupling factor I from chloroplasts with ribonucleic acid and lipids // J. Biol. Chem.-1969.-244, N 5.-P. 1332-1338.

65. Balasubramanian R., Zorn H., PapenbrockJ. Quantification and fatty acid profiles of sulfolipids in two halophytes and a glycophyte grown under different salt concentrations // Z . Naturforsch.-2004.-59c, N 11-12.-P. 835-842.

66. Debez A., Saadaoui D., Balasubramanian R., Ouerghi Z., Koyro H.-W., Huchzermeyer B., Abdelly C. Leaf H+-ATPase activity and photosynthetic capacity of Cakile maritima under increasing salinity // Environ. Exp. Bot.-2006.-57, N 3.P. 285-295.

67. Vishwanath B. S., Eichenberger W., Frey F. J., Frey B. M. Interaction of plant lipids with $14 \mathrm{kDa}$ phospholipase $\mathrm{A}_{2}$ enzymes // Biochem. J.-1996.-320, N 1.-P. 93-99.

68. Lambers $J$. W., Terpstra $W$. Inactivation of chlorophyllase by negatively charged plant membrane lipids // Biochim. et Biophys. Acta.-1985.-831, N 2.-P. 225-235.

69. Di Baccio D., Quartacci M. F., Dalla Vecctila F., La Rocca $N$., Rascto N., Navari-lzzo F. Bleaching herbicide effects on plastids of dark-grown plants: lipid composition of etioplasts in amitrole and norflurazon-treated barley leaves // J. Exp. Bot.-2002.-53, N 376.-P. 1857-1865.

70. Kurihara H., Mitani T., Kawabata J., Hatano M. Inhibitory effect on the $\beta$-glucosidase reaction by the aggregated state of sulfoquinovosyl-diacylglycerol // Bios. Biotechnol. Biochem.-1997.-61, N 3.-P. 536-538.

71. Kurihara H., Tada S., Takahashi K., Hatano M. Digalactosyldiacylglycerol suppression of inhibition by sulfoquinovosyl-diacylglycerol of $\beta$-glucosidase // Bios. Biotechnol. Biochem.-1996.-60, N 5.-P. 932-934.

72. Gustafson K. R., Cardelina J. H., Fuller R. W., Weislow O. S., Kiser R. F., Snader K. M., Patterson G. M. L., Boyd M. R. AIDS-antiviral SL from cyanobacteria (blue-green algae) // J. Nat. Cancer Inst.-1989.-81, N 16.-P. 1254-1258.

73. Hanashima S., Mizushina Y., Yamazaki T., Ohta K., Takahashi S., Sakaguchi K., Sugawara F. Synthesis of sulfoquinovosyl acylglycerols, inhibitors of eukaryotic DNA polymerase $\alpha$ and $\beta / /$ Bioorg. and Med. Chem.-2001.-9, N 2.P. 367-376.

74. Ohta K., Mizushina Y., Hirata N., Takemura M., Sugawara F., Matsukage A., Yoshida S., Sakaguchi K. Sulfoquinovosyldiacylglycerol, KM043, a new potent inhibitor of eukaryotic DNA polymerases and HIV-reverse transcriptase type 1 from a marine red alga, Gigartina tenella // Chem. and Pharm. Bull. (Tokyo).-1998.-46, N 4.-P. 684- 686. 
75. Loya S., Reshef V., Mizrachi E., Silberstein C., Rachamin Y., Carmeli S., Hizi A. The inhibition of the reverse transcriptase of HIV-1 by the natural sulfoglycolipids from cyanobacteria: contribution of different moieties to their high potency // J. Nat. Prod.-1998.-61, N 7.-P. 891-895.

76. Ogawa A., Murate T., Izuta S., Takemura M., Furuta K., Kobayashi J., Kamikawa T., Nimura Y., Yoshida S. Sulfated glycoglycerolipid from an archaebacterium inhibits eukaryotic DNA polymerase $\alpha, \beta$ and retroviral reverse transcriptase and affects methyl methanesulfonate cytotoxicity // Int. J. Cancer.-1998.-76, N 4.-P. 512-518.

77. Keegstra K., Cline K. Protein import and routing systems of chloroplasts // The Plant Cell.-1999.-11, N 4.-P. 557-570.

78. Van't Hof R., Demel R. A., Keegstra K., de Kruijff B. Lipid-peptide interactions between fragments of the transit peptide of ribulose-1,5-bisphosphate carboxylase/oxygenase and chloroplast membrane lipids // FEBS Lett.-1991.-291, N 2.-P. 350-354.

79. Van't Hof R., van Klompenburg W., Pilon M., Kozubek A., de Korte-Kool G., Demel R. A., Weisbeek P. J., de Kruijff B. The transit sequence mediates the specific interaction of the precursor of ferredoxin with chloroplast envelope membrane lipids // J. Biol. Chem.-1993.-268, N 6.-P. 4037-4042.
80. Pilon M., Wienk H., Sips W., de Swaaf M., Talboom I., van't Hof R., de Korte-Kool G., Demel R., Weisbeek P., de Kruijff $B$. Functional domains of the ferredoxin transit sequence involved in chloroplast import // J. Biol. Chem.-1995.-270, N 8.-P. 3882-3893.

81. Horniak L., Pilon M., Van't Hof R., De Kruijff B. The secondary structure of the ferredoxin transit sequence is modulated by its interaction with negatively charged lipids // FEBS Lett.-1993.-334, N 2.-P. 241-246.

82. Lancelin J.-M., Bally I., Arland G. J., Blackedge M., Gans P., Stein M., Jacquot J.-P. NMR structure of ferredoxin chloroplastic transit peptide from Chlamydomonas reinhardtii promoted by trifluoroethanol in aqueous solution // FEBS Lett.-1994.-343, N 3.-P. 261-266.

83. Pain D., Blobel G. Protein import into chloroplasts requires a chloroplast ATPase // Proc. Nat. Acad. Sci. USA.-1987.-84, N 10.-P. 3288-3292.

УДК 755.121

Надійшла до редакції 15.12.07 